\title{
KARAKTERISTIK DAN PREFERENSI KONSUMEN DURIAN LOKAL DI KABUPATEN JEMBER
}

\section{CHARACTERISTICS AND PREFERENCES OF LOCAL DURIAN CONSUMERS IN JEMBER REGENCY}

\author{
Balya Elok Sayyidah, Soetriono, Raharto Sugeng \\ Program Studi Agribisnis Fakultas Pertanian Universitas Jember \\ E-mail : sayyidah_elok@yahoo.com
}

\begin{abstract}
ABSTRAK
Durian merupakan salah satu jenis buah-buahan yang bergizi tinggi dan mempunyai peluang besar untuk dikembangkan. Penelitian ini bertujuan untuk: (1) mendeskripsikan karakterisitik konsumen durian lokal; (2) menganalisis faktor-faktor dominan yang mempengaruhi terhadap preferensi konsumen buah durian lokal; dan (3) membuat strategi pengembangan minat konsumen terhadap buah durian lokal. Penentuan daerah penelitian secara purposive method yakni di Kabupaten Jember. Metode pengambilan sampel dilakukan secara nonprobability sampling dan incidental sampling. Metode analisis data dengan deskriptif, analisis faktor dan analisis Medan Kekuatan (FFA). Kesimpulan penelitian: (1) Karakteristik konsumen durian lokal berdasarkan kategori: (a) umur mayoritas responden berada pada golongan umur 27-37 tahun dengan proporsi $45,16 \%$, (b) jenis kelamin konsumen mayoritas adalah perempuan dengan jumlah 47 orang $(50,54 \%)$, (c) pekerjaan, mayoritas bekerja sebagai pegawai swasta dengan jumlah 40 orang atau sebesar $43,01 \%$, (d) tingkat pendidikan, mayoritas berada pada tingkat pendidikan SMP dengan jumlah 60 orang atau sebesar 64,52\%, (e) jumlah anggota keluarga, mayoritas memiliki 2 hingga 4 orang dengan proporsi $69 \%$, dan kategori (f) tingkat pendapatan, mayoritas berada pada kategori sedang dengan jumlah responden 48 orang atau sebesar 51,61\%. (2) Dari 11 faktor yang mempengaruhi dalam preferensi konsumen memilih buah durian lokal terkategori menjadi 5 faktor yakni: (a) faktor warna kulit buah (hijau-muda, hijau-tua, hijau-cokelat, dan cokelat-tua); (b) faktor panjang duri (pendek, sedang, dan panjang); (c) faktor warna daging cerah (kuning dan merah); (d) faktor tekstur (lembut-basah, lembut-kering/pulen, berkrim, dan berserat); dan (e) faktor rasa buah durian (manis-pahit, manis-legit, manis-sedang, dan kurang manis).
\end{abstract}

Kata kunci: Karakteristik durian lokal, preferensi durian lokal, analisis faktor, dan strategi

\section{ABSTRACT}

Durian is one type of highly nutritious fruit and has a great chance to develop. This research aimed to: (1) describe the characteristics of local durian consumers; (2) analyze the dominant factors affecting local durian consumer preferences; and (3) make the development strategiesfor consumer interest towards local durian. The research area was determined by purposive method i.e. Jember Regency. Sampling applied nonprobability sampling and incidental sampling. Dataanalysis used descriptive method, factor analysis and Force Field analysis (FFA). It is concluded that: (1) Characteristics of local durian consumers by category: (a) based on the age,45.16\% belong to 27-37 years old, (b) based on the sex, 47 respondents are women, (c) most of them, $43.01 \%$ working in private employees, $(d)$ while majority $64.52 \%$ reached junior high school, (e) in the other hand based on househeld size, 69\% has 2-4 family members, $(f)$ as well as $51.61 \%$ earn $R p$ 1.500.000 - Rp 2.500.000. (2) There are 5 factors affecting consumers preferensi an local durian such as: (a) fruit skin color (b) spine length; (c) meat color brightness; (d) texture; and (e) taste. Some alternative strategies that can be taken in developing the consumers' interest in local 
durian include: (a) applying technology of quality seeds; (b) optimizing the production either mechanically and chemically; (c)improvingthe quality in cultivation, harvest and post-harvest.

Keywords: Characteristics of local durian, durian local preferences, factor analysis, and strategies

\section{PENDAHULUAN}

Durian (Durio zibethinus Murr.) merupakan tanaman buah tropika yang sangat populer dan dijuluki sebagai raja buah . Durian merupakan salah satu jenis buahbuahan yang bergizi tinggi dan mempunyai peluang besar untuk dikembangkan. Selain mempunyai aroma yang khas dan berasa lezat, buah durian juga mempunyai kandungan gizi yang relatif lengkap dibandingkan buah-buahan lainnya (Santoso et al, 2008 )

Kabupaten Jember, merupakan salah satu daerah berpotensi sebagai penghasil durian, tepatnya pada posisi ke lima setelah Kabupaten Pasuruan, Jombang, Ponorogo, Malang. Produksi buah durian di Kabupaten Jember berkisar 3.402 ton dengan luas areal sekitar 248 Ha (Sobir dan Napitupulu, 2010).

Pengembangan buah durian lokal pada saat musimnya dapat ditemukan di beberapa daerah di Kabupaten Jember seperti di daerah Panti, Garahan dan Sumberjambe. Durian lokal merupakan alternatif konsumsi yang mempunyai rasa yang khas dan harganya cukup terjangkau konsumen. Durian lokal dikenal memiliki rasa yang khas yaitu manis, legit dan sedikit pahit. Aroma, bentuk buah, warna kulit dan warna dagingpun juga berbeda-beda. Bentuk durian lokal yang beragam ini mempunyai nama sendiri-sendiri ada yang dinamakan durian kerbau, durian gading dan lain-lain. (Saung Sumberjambe, 2011).

Perkembangan jaman telah mengubah sikap konsumen menjadi lebih bebas dalam memilih produk yang akan dibeli. Hal ini terjadi karena pasar menyediakan berbagai pilihan produk yang sangat banyak, sehingga keputusan untuk membeli ada pada diri konsumen dan tentunya konsumen berhak membeli produk sesuai dengan kriteria yang telah ditetapkan. Dengan demikian, pemasar berkewajiban untuk lebih memahami perilaku konsumen dan dapat memproduksi suatu produk yang dapat memenuhi kebutuhan dan kualifikasi konsumen.

Adanya karateristik konsumen yang bermacam-macam seperti tingkat pendapatan, pendidikan, dll, disinyalir mempengaruhi konsumsi/membeli buah durian lokal. Hal ini dikarenakan, konsumen memiliki berbagai kriteria untuk membeli produk, diantaranya adalah membeli produk yang sesuai dengan kebutuhannya, seleranya, dan daya belinya. Konsumen akan memilih produk yang mutunya lebih baik dengan harga yang lebih murah (Sumarwan, 2002).

Kondisi tersebut mengharuskan pedagang untuk jeli dalam memilih varietas durian yang disukai konsumen, karena akibat ketidaktepatan pemilihan tersebut akan merugikan pedagang. Dengan demikian maka penelitian tentang preferensi konsumen terhadap buah durian lokal penting untuk membantu petani dan pedagang mengenali karakteristik buah yang diinginkan konsumen. Penganalisaaan karateristik dan preferensi konsumen memberikan wawasan dalam penyusunan startegi pengembangan minat konsumen durian lokal. Strategi pengembangan diharapkan dapat memberikan solusi khususnya perencanaan jenis produk durian lokal yang sesuai dengan preferensi konsumen.

Tujuan penelitian yakni: Mendeskripsikan karakteristik konsumen durian lokal, (2) Menganalisis faktor-faktor dominan yang mempengaruhi terhadap preferensi konsumen buah durian lokal, (3) Membuat strategi pengembangan minat konsumen terhadap buah durian lokal. 


\section{METODE PENELITIAN}

Penentuan daerah penelitian dilakukan secara sengaja (Purposive Method) yakni di Kabupaten Jember di kios durian lokal di Kecamatan Sumbersari (depan SMP 2 Jember), Kecamatan Rambipuji, dan Kecamatan Mayang. Pemilihan Kabupaten Jember dilakukan secara sengaja (purposive) dengan pertimbangan bahwa Kabupaten Jember merupakan salah satu daerah berpotensi sebagai penghasil durian lokal.

Metode pengambilan sampel dalam penelitian ini menggunakan sampel tanpa peluang (nonprobability sampling), dimana setiap anggota populasi tidak diketahui peluang atau kemungkinan terpilih sebagai sampel. Penyebaran kuesioner dilakukan dengan menggunakan metode sampling insidental, dimana penentuan sampel berdasarkan kebetulan, yaitu siapa saja yang secara kebetulan/insidental bertemu dengan peneliti dapat digunakan sebagai sampel, bila dipandang orang yang kebetulan ditemui itu cocok sebagai sumber data/responden (Sugiyono, 2012). Dengan menggunakan Rumus Slovin, jumlah sampel penelitian pada penelitian ini adalah 93 orang, sampel tersebut kemudian dibagi atas 3 kios, masingmasing 31 orang responden yang membeli durian di kios SMP 2 Jember, 31 responden konsumen durian di Kecamatan Rambipuji, dan 31 konsumen durian di kios Buah Kecamatan Mayang.

Metode analisis data yang digunakan untuk menjawab tujuan pertama yaitu tentang karateristik konsumen durian lokal berupa usia, pendidikan, pekerjaan, pendapatan, sumber informasi, dan pengetahuan konsumsen durian lokal dikaji dengan bantuan analisis deskriptif. Permasalahan kedua mengenai preferensi konsumen terhadap buah durian lokal dikaji menggunakan analisis faktor regresi dengan software SPSS. Sedangkan permasalahan ketiga mengenai penyusunan startegi pengembangan minat konsumen durian lokal, dikaji dengan bantuan analisis FFA (Force
Field Analysis). Kevalidan dan kesahihan data pada kuesioner yang diisi oleh responden digunakan uji validitas dan uji reliabilitas.

\section{HASIL DAN PEMBAHASAN}

\section{Karakteristik Konsumen Buah Durian Lokal berdasarkan:}

a) Umur

Responden dari hasil penelitian ini memiliki karakteristik yang terbagi kedalam 4 kategori kelompok umur yakni 1) kelompok/golongan umur 16-26 tahun; 2) 27-37 tahun; 3) 38-48 tahun; dan 4) 49-60 tahun. Dari keempat kategori golongan umur tersebut, mayorits responden berada pada golongan umur 27-37 tahun dengan proporsi $45,16 \%$. Sedangkan untuk golongan umur 49-60 tahun merupakan responden terkecil dengan proporsi 3,23\%.

b) Jenis Kelamin

Berdasarkan data yang telah terkumpul mengenai karakteristik jenis kelamin responden, dapat diketahui bahwa mayoritas responden adalah Perempuan dengan jumlah 47 orang $(50,54 \%)$, sedangkan responden Laki-laki sejumlah 46 orang $(49,46 \%)$. Jumlah dari responden Perempuan dan Lakilaki ini hanya selisih satu orang saja, meskipun demikian dari penelitian ini dapat dikatakan konsumen buah durian lokal mayoritas Perempuan.

c) Pekerjaan

Responden konsumen buah durian lokal berdasarkan karakteristik pekerjaan, mayoritas bekerja sebagai pegawai Swasta dengan jumlah 40 orang atau sebesar 43,01\% dari total responden. Sedangkan profesi sebagai Ibu Rumah Tangga dan yang bekerja di BUMN menempati jumlah paling sedikit yakni hanya 1 orang saja $(1,08 \%)$. Untuk responden Pensiunan juga sedikit yang ditemui yakni sejumlah 3 orang $(3,23 \%)$, PNS sejumlah 25 orang $(26,88 \%)$, dan responden Wiraswasta sejumlah 23 orang atau sebesar $24,73 \%$. Hal ini menunjukkan 
bahwa buah durian lokal cukup diminati oleh berbagai kalangan dari berbagai jenis pekerjaan.

d) Tingkat Pendidikan

Responden buah durian lokal terbesar berada pada tingkat pendidikan SMP dengan jumlah 60 orang atau sebesar 64,52\%. Untuk konsumen dengan tingkat pendidikan SD sejumlah 3 orang $(3,23 \%)$, responden dengan tingkat pendidikan SMA hanya 2 orang saja atau hanya sebesar $2,15 \%$. Sedangkan untuk responden tingkat Sarjana sejumlah 28 orang $(30,11 \%)$. Tingkat pendidikan konsumen akan berpengaruh pada kemampuan untuk menerima dan juga kemampuan dalam mengambil keputusan dalam pembelian.

e) Jumlah Anggota Keluarga

Responden dalam penelitian ini sebagian besar memiliki jumlah keluarga 2 hingga 4 orang dengan proporsi $69 \%$. Jumlah anggota keluarga akan menentukan jumlah buah durian lokal yang akan dibeli/dikonsumsi. Keluarga yang memiliki jumlah anggota keluarga yang lebih kecil tentunya akan lebih mudah untuk kebutuhan buah duriannya.

f) Pendapatan Keluarga

Pendapatan responden dalam penelitian ini terbagi kedalam 4 kategori yakni kategori pendapatan Sangat Tinggi, Tinggi, Sedang, dan Rendah. Berdasarkan hasil penelitian menunjukkan bahwa mayoritas tingkat pendapatan konsumen buah durian lokal yakni berada pada kategori Sedang dengan jumlah responden 48 orang atau sebesar $51,61 \%$. Sedangkan untuk konsumen dengan pendapatan Sangat Tinggi hanya terdapat 8 orang responden atau hanya sebesar $8,60 \%$ saja. Hal ini menunjukkan bahwa konsumen buah durian lokal berasal dari pendapatan sedang, karena buah durian lokal dapat dikonsumsi oleh siapa saja dan mempunyai harga yang terjangkau.

\section{Faktor Dominan Yang Mempengaruhi Preferensi Konsumen}

Preferensi konsumen buah durian dalam penelitian ini dipengaruhi oleh 11 faktor. Dari 11 faktor tersebut dilakukan uji
Analisis Faktor. Pengujian pertama pada analisis faktor preferensi konsumen buah durian ini menggunakan hasil uji Keiser Meyer Olkin (KMO) and Bartlett's Test untuk melihat apakah faktor yang diteliti memiliki nilai Measure of Sampling Adequency (MSA) lebih besar dari 0,5 dan Signifikansi $\leq 0,05$. Selanjutnya melihat nilai Anti-image Correlation dari masing-masing variabel apakah sudah melebihi dari 0,5. Jika hasil Anti-image Correlation dari masingmasing variabel $<0,5$ maka variabel tersebut harus dikeluarkan dari model dan melakukan kembali analisis hingga seluruh Anti-image Correlation terbentuk diatas 0,5. Selanjutnya, nilai Anti-Image Correlation pada angka korelasi yang bertanda $a$ (arah diagonal dari kiri atas ke kanan bawah) yang juga menunjukkan masih terdapat beberapa variabel dengan nilai dibawah 0,5 (Lihat Lampiran 4). Dengan hasil ini langkah yang harus dilakukan selanjutnya yakni menganalisis kembali dengan mengeluarkan satu per satu variabel yang memiliki nilai Anti-Image Correlation dibawah 0,5 dimulai dari nilai yang terkecil dahulu. Pengujian tersebut dilakukan hingga diperoleh nilai KMO-MSA diatas 0,5; signifikansi $\leq 0,05$; dan nilai Anti-image Correlation variabelvariabel yang diuji diatas 0,5 .

Pada analisis selanjutnya dari variabelvariabel preferensi konsumen dalam memilih buah durian, terdapat 6 variabel yang dikeluarkan. Variabel tersebut diantaranya bentuk buah (X1), ukuran buah (X2), bau/aroma buah (X3) warna daging pucat (X4), ketebalan daging (X5), dan ukuran biji (X6). Setelah melakukan eliminasi terhadap 6 variabel, hasilnya menunjukkan seperti pada Tabel 1 dan 2 berikut.

Tabel 1. Nilai Uji Keiser-Meyer Olkin dan Signifikansi

\begin{tabular}{lc}
\hline \multicolumn{1}{c}{ Keterangan } & Nilai \\
\hline KMO-MSA & 0,665 \\
Df & 10 \\
\hline Sig Bartlett's Test of Sphericity & 0,001 \\
\hline
\end{tabular}


Berdasarkan Tabel 1 menunjukkan bahwa ketika 6 variabel dikeluarkan, nilai MSA sebesar 0,665 lebih besar dari 0,5. Sedangkan nilai signifikansi yang terbentuk sebesar $0,001 \leq 0,05$. Hasil MSA dan signifikansi ini dapat diartikan bahwa variabel dan sampel yang terbentuk dapat dilakukan analisis lebih lanjut. Dasar dari nilai MSA dapat digunakan untuk menganalisis setiap variabel dalam Anti Image Matrices. Tabel 1 merupakan hasil analisis dari variabel warna kulit buah, panjang duri, warna daging cerah, tekstur, dan rasa.
Langkah selanjutnya dari tahapan analisis faktor yakni menentukan nilai Antiimage Correlation dari masing-masing variabel yang harus di atas 0,5 . Tabel 2 menunjukkan hasil Anti-image Correlation dari 5 variabel. Dari Tabel 2 di bawah ini terlihat bahwa nilai Anti-image Correlation dari 5 variabel pada angka korelasi yang bertanda $a$ telah lebih besar dari $0,5(a>$ 0,5 ). Oleh karena $a>0.5$, maka seluruh variabel dan sampel yang ada sudah bisa dianalisis lebih lanjut dengan melakukan proses Extraction dan Rotation untuk melihat hubungan antar variabel dalam satu faktor.

Tabel 2. Nilai Anti-image Correlation Preferensi Konsumen Buah Durian

\begin{tabular}{|c|c|c|c|c|c|}
\hline $\begin{array}{c}\text { Variabel/Korela } \\
\text { si }\end{array}$ & warna kulit & Panjang duri & warna daging cerah & Tekstur & Rasa \\
\hline warna kulit & $.633^{\mathrm{a}}$ & -.088 & . 317 & .093. & .301 \\
\hline panjang duri & -.088 & $.745^{\mathrm{a}}$ & -.004 & -.136 & .261 \\
\hline $\begin{array}{l}\text { warna daging } \\
\text { cerah }\end{array}$ & . 317. & -.004 & $.683^{\mathrm{a}}$ & 等. & -.098 \\
\hline Tekstur & .093 & -.136 & .045 & $.639^{\mathrm{a}}$ & .327 \\
\hline Rasa & .301 & .261 & -.098 & .327 & $.654^{\mathrm{a}}$ \\
\hline
\end{tabular}

Sumber: Data Primer Diolah, 2016

Tahapan selanjutnya yang perlu dinilai yakni pada hasil Communalities. Communalities pada dasarnya adalah jumlah varians yang bisa dinyatakan dalam persentase dari suatu variabel mula-mula yang bisa dijelaskan oleh faktor yang ada. Hasil varians dari masing-masing variabel dapat dicermati pada Tabel 3 berikut.

Tabel 3. Hasil Communalities Variabel

\begin{tabular}{lc}
\hline \multicolumn{1}{c}{ Variabel } & Extraction \\
\hline Warna kulit & 0,687 \\
Panjang duri & 0,508 \\
Warna daging cerah & 0,658 \\
Tekstur & 0,628 \\
Rasa & 0,659 \\
\hline
\end{tabular}

Sumber: Data Primer Diolah, 2016

Tabel 3 adalah nilai varians dari masingmasing faktor. Jika di urutkan dari nilai varians terbesar hingga terkecil, maka urutannya yakni:

1) Warna kulit $(0,687)$; Faktor warna kulit memiliki nilai communalities sebesar $0,687(68,7 \%)$ yang dapat diartikanbahwa sebesar $68,7 \%$ varians faktor warna kulit dapat dijelaskan oleh variabel hijau muda, hijau tua, hijau cokelat, dan cokelat tua. Semakin besar nilai communalities berarti semakin erat hubungan antar variabel dengan faktor warna kulit.

2) Rasa $(0,659)$; faktor rasa buah memiliki nilai communalities sebesar $65,9 \%$ yang dapat diartikan bahwa varians rasa buah dapat dijelaskan oleh variabel manispahit, manis legit, manis sedang, dan kurang manis.

3) Warna daging cerah $(0,658)$; faktor warna daging cerah memiliki nilai 
communalities sebesar $65,8 \%$ sehingga hal ini dapat diartikan bahwa varians faktor warna daging cerah dapat dijelaskan oleh variabel kuning dan merah.

4) Tekstur (0,628); faktor tekstur daging buah durian memiliki nilai communalities sebesar $62,8 \%$ yang dapat diartikan bahwa varians faktor ini dapat dijelaskan oleh variabel pembentuknya yakni buah durian dengan tekstur lembut-basah, lembut-kering, berkrim, dan berserat.

5) Panjang duri $(0,508)$ memiliki nilai communalities sebesar $50,8 \%$ sehingga hal ini mengindikasikan bahwa varians faktor panjang duri dapat dijelaskan oleh variabel pendek, sedang, dan panjang.

Interpretasi selanjutnya dari hasil analisis faktor ini yakni pada Total Variance Explained. Hasil dari Total Variance Explained ini selanjutnya dapat dilihat pada Tabel 4. Tabel 4, jumlah faktor bersama yang terbentukadalah sebanyak variabel penyusunnya satu dimensi, sebanyak 5 faktor bersama. Faktor bersama dengan nilai initial eigenvaluetotal yang $\geq 1$, merupakan faktor yang mewakili sub-variabel pembentuknya.Sumbangan faktor bersama yang terbentuk dalam analisis dapat dilihat dari nilaiTotal variance explained.Dari hasil analisis dapat diketahui bahwa yang memiliki nilai totalinitial eigenvalue $\geq 1$ yakni Faktor warna kulit dan panjang duri. Untuk lebih jelasnya dapat dicermati sebagai berikut. Angka eigenvalues yang $<1$ tidak digunakan dalam menghitung jumlah faktor yang terbentuk.

Dari 5 faktor pengukuran atau dimensi terbentuk dua faktor bersama, yaitu faktor 1 yakni warna kulit buah dengan persentase variansnya sebesar 49,306\% dan faktor kedua yakni panjang duri dengan persentase varians $20,281 \%$. Persentase kumulatif varians yang terbentuk dari kedua faktor bersama adalah sebesar $69,587 \%$ dan sisanya $30,413 \%$ terdiri atas 3 faktor bersama (warna daging cerah, tekstur, dan rasa buah) yang masing-masing nilainya yakni 14,836\%; 9,103\%; dan $6,475 \%$.

Jika total varience menjelaskan dasar jumlah faktor yang didapat dengan perhitungan angka, maka Scree Plot menunjukkan hal tersebut dengan grafik. Berikut tampilan hasil grafik Scree Plot.

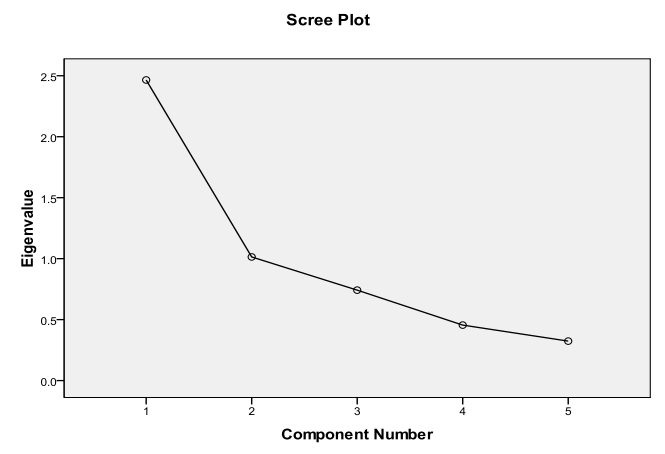

Gambar 1. Grafik Scree Plot Sebaran Nilai Eigenvalue

Dari gambar Scree Plot terlihat bahwa dari satu ke dua faktor (garis dari sumbu Component Number 1 ke 2) menunjukkan garis menurun dengan cukup tajam yang dikarenakan nilai Eigenvalue 1 yang melebihi angka 2 kemudian turun drastis ke angka 1 pada component number 2 . Selanjutnya, untuk componentnumber 3-5 menunjukkan grafik scree plot yang cenderung mengalami penurunan namun tidak setajam pada number 1-2.

Selanjutnya, menelaah nilai Component Matrix. Setelah diketahui bahwa dua faktor (2) yakni warna kulit dan panjang duri yang paling optimal dan yang memiliki nilai total eigenvalue $\geq 1$, maka tabel Component Matrix menunjukkan distribusi kelima faktor tersebut pada 2 faktor yang terbentuk. Angka-angka yang terdapat pada tabel component matrix adalah factor loadings, yang menunjukkan nilai korelasi suatu faktor dengan fator 1 warna kulit dan faktor 2 panjang duri.tanda positif (+) dan negatif (-) pada factor loading hanya menunjukkan arah hubungan yang bersifat searah atau berlawanan. 
Nilai faktor loading ditentukan dari nilai yang > 0,5. Jika dalam korelasi terdapat dua atau lebih faktor loading yang nilainya lebih besar dari 0,5 maka dilakukan proses Rotation. Dari hasil Component Matrix terdapat dua korelasi yang memiliki nilai > 0,5 yakni pada faktor Tekstur degan nilai korelasi 0,657 dan 0,598 serta faktor Rasa 0,691 dan 0,530. Dengan hasil ini maka langkah selanjutnya yakni melakukan Rotation. Proses Rotation ini memperlihatkan distribusi variabel yang lebih jelas dan nyata. Adapun hasil dari Rotated Component Matrix dapat dilihat dari tampilan berikut.

Tabel 5. Hasil Rotated Component Matrix

\begin{tabular}{lcc}
\hline & \multicolumn{2}{c}{ Component } \\
\cline { 2 - 3 } & \multicolumn{1}{c}{1} & \multicolumn{2}{c}{2} \\
\hline Warna Kulit & .850 & .238 \\
Panjang Duri & .807 & .128 \\
Warna Daging Cerah & -.684 & -.134 \\
Tekstur & .146 & .876 \\
Rasa & -.214 & -.844 \\
\hline
\end{tabular}

Sumber: Data Primer Diolah, 2016

Dari Tabel 5 dapat diinterpretasikan bahwa:

a. Faktor warna kulit memiliki nilai distribusi variabel yang lebih dari 0,5 yakni sebesar 0.850 yang terdapat pada kolom Component Faktor 1.

b. Faktor panjang duri memiliki nilai distribusi variabel lebih besar dari 0,5 yakni 0.807 yang terdapat pada kolom Component Faktor 1.

c. Faktor warna daging cerah memiliki nilai distribusi variabel lebih besar dari 0,5 yakni 0.684 dengan tanda negatif yang terdapat pada Component Faktor 1.

d. Faktor tekstur memiliki nilai distribusi variabel lebih besar dari 0.5 yakni sebesar 0.876 yang terdapat pada kolom Component Faktor 2.

e. Faktor rasa memiliki nilai distribusi variabel lebih besar dari 0.5 yakni sebesar 0.844 dengan tanda negatif yang terdapat pada kolom Component Faktor 2.
Tabel 6. Hasil Component Transformation Matrix

\begin{tabular}{|c|c|c|}
\hline Component & 1 & 2 \\
\hline 1 & .785 & .620 \\
\hline 2 & .620 & -.785 \\
\hline
\end{tabular}

Sumber: Data Primer Diolah, 2016

Tabel 6 menjelaskan tampilan dari hasil Component Transformation Matrix.terlihat bahwa pada angka-angka diagonal dari kiri atas ke kanan bawah memiliki nilai lebih besar dari 0,5. Hal ini membuktikan kedua faktor (component) yang terbentuk sudah tepat, karena memiliki nilai korelasi yang tinggi. Nilai diagonal tersebut yakni 0,785 pada component 1 dan 0,785 pada component 2 .

Dari hasil Analisis Faktor yang telah dilakukan, maka dapat disimpulkan bahwa hipotesis kedua yang dikemukakan dalam penelitian ini ditolak. Dari 11 faktor yang dianalisis ternyata preferensi konsumen dalam memilih buah durian terkategori menjadi 5 faktor yakni:

1) faktor warna kulit buah (hijau-muda, hijau-tua, hijau-cokelat, dan cokelat- tua);

2) faktor panjang duri (pendek, sedang, dan panjang);

3) faktor warna daging cerah (kuning dan merah);

4) faktor tekstur(lembut-basah, lembutkering/pulen, berkrim, dan berserat); dan

5) faktor rasa buah durian (manis-pahit, manis-legit, manis-sedang, dan kurang manis)

\section{Strategi Pengembangan Minat Kon- sumen Terhadap Buah Durian Lokal}

Penentuan strategi pengembangan minat konsumen terhadap buah durian lokal dapat diketahui melalui Analisis Medan Kekuatan (FFA). Dalam penelitian ini, pengembangan minat konsumen terhadap buah durian lokal menunjukkan terdapat beberapa faktor yang teridentifikasi sebagai faktor pendorong dan penghambat. 
Faktor Pendorong direpresentasikan oleh variabel D1 (Kabupaten Jember penghasil durian lokal), D2 (Durian lokal memiliki harga relatif lebih murah dibanding durian impor), D3 (Jenis durian lokal cukup beragam), D4 (Kios durian lokal tersebar di Kabupaten Jember), D5 (Konsumen buah durian lokal cukup banyak), dan D6 (Permintaan dari luar daerah).

Faktor Penghambat direpresentasi-kan oleh variabel H1 (Produksi durian tergantung musim), H2 (Ukuran buah durian yang relatif kecil), H3 (Durian lokal tidak terjaga kualitasnya), H4 (Pandangan konsumen mengenai kualitas durian lokal yang kurang baik), H5 (Kurangnya promosi terhadap duurian lokal), dan H6 (Keberadaan durian impor).

Hasil analisis faktor-faktor pendorong dan penghambat diperoleh nilai bobot faktor (TNB) untuk faktor kekuatan adalah 4,53, faktor peluang sebesar 2,61, faktor kelemahan sebesar 3,58 dan faktor ancaman sebesar 3,16. Keseluruhan total faktor pendorong menunjukkan nilai sebesar 7,14 dan hasil analisis faktor-faktor penghambat diperoleh nilai sebesar 6,73.

Berdasarkan hasil FFA selanjutnya dapat ditentukan strategi pengembangan dalam upaya meningkatkan preferensi konsumen terhadap durian lokal diantaranya:

\section{Penerapan teknologi dengan bibit unggul}

Untuk menghasilkan buah yang unggul, maka dimulai dari penggunaan bibit unggul, baik yang dikembangkan dari pembuatan bibit unggul nasional maupun introduksi. Secara garis besar penciptaan bibit unggul tersebut dilakukan dengan penyatuan batang bawah yang unggul secara sistem perakarannya dengan batang atas yang unggul dari segi produksi. Benih unggul tanaman buah dihasilkan dari penangkar benih yang tersebar di seluruh wilayah Indonesia. Khusus untuk benih tanaman durian sentra perbenihannya ada di Batu
Jamus Pendem (Jawa Tengah), Majalengka, Bogor, (Jawa Barat).

Selama ini, di Kabupaten Jember sendiri durian yang paling banyak dikenal oleh masyarakat adalah durian yang dihasilkan dari Sumberjambe dan Panti. Petani dari kedua lokasi tersebut menggunakan bibit lokal dan mayoritas duriannya berbuah musiman dari Agustus-November. Mengingat akan tingginya minat konsumen, buah durian yang bersifat musiman, serta anggapan tentang kualitas buah durian lokal yang kurang baik maka penerapan penanaman varietas bibit unggul dirasa mampu untuk mengatasi berbagai kondisi tersebut. Pemakaian bibit varietas unggul tersebut mampu memberikan hasil buah durian yang lebih banyak dari segi produksi, memiliki kualitas buah yang baik, rasa yang manis, dan cepat berbuah.

\section{Optimalisasi produksi}

Durian adalah jenis tanaman buah yang mulai bisa dipanen pada umur 4-5 tahun pada durian genjah. Umumnya semua jenis durian hanya berbuah pada musimnya saja. Musim durian biasanya terjadi pada bulan AgustusNovember, sementara konsumen durian biasanya menginginkan untuk dapat mengkonsumsi durian tidak hanya pada musimnya saja, namun di luar musim pula. Mengenai hal tersebut, perlu adanya upaya peningkatan optimalisasi produksi durian agar dapat berbuah pada bulan-bulan lain selain bulan Agustus-November.

Tanaman durian dapat dirangsang agar dapat berbuah di luar musimnya memerlukan beberapa teknik khusus. Petani durian di Kabupaten Jember dapat melakukan optimalisasi produksi melalui upaya membuahakn durian di luar musim dengan 2 cara yakni secara mekanis dan kimiawi.

\section{Peningkatan kualitas}

Konsumen durian lokal mempunyai anggapan bahwa durian lokal memiliki kualitas kurang baik dibanding dengan durian impor. Sedangkan dari segi peluang usaha durian dalam negeri sangat baik, karena kebijakan pemerintah untuk membatasi 
impor produk hortikultura termasuk durian, memberikan peluang sebagai substitusi impor yang pada tahun 2010 mencapai volume 34.705 ton atau sekitar $4,95 \%$ dari total produksi durian nasional yang mencapai 700.890 ton. Namun demikian, peluang ini belumsepenuhnya dapat diambil karena fakta dilapangan menunjukkan bahwa durian di Indonesia menghadapi masalah pada kualitas buah.

Tiga kasus berkaitan dengan kualitas yang banyak ditemui, yaitu buah mengkal (matang sebagian),daging buah lunak dan berair, serta buah yang sebagian dagingnya mengering. Pokok permasalahan kualitas buah tersebut diduga akibat dari pelaksanaan budidaya yang belum mengacu pada prosedur budidaya yangbaik dan benar. Buah yang basah dan rasanya hambar banyak muncul apabila saat pematangan buah diiringi oleh curah hujan yang tinggi. Sulur buah basah atau disebut wet core disebabkan oleh akumulasi air yang berlebihan dalam tanah dan kekurangan hara kalium (K). Kondisi buah mengering atau seperti terbakar sebagian, diduga karena kekurangan boron (Bo). Berbeda dengan akibat kekurangan $\mathrm{Ca}$ yang pucat dan mengeras, umumnya ditemui secara bersamaan dalam satu hamparan kebun. Karena walaupun masalah defisiensi yang menonjol hanya terhadap ketiga unsur $\mathrm{Ca}, \mathrm{K}$, dan $\mathrm{Bo}$, namun sebenarnya berkaitan juga dengan unsur yang lain selama dalam proses pertumbuhan, sehingga penanganan masalahnya dianjurkan dilakukan secara menyeluruh melalui paket pemupukan secara tepat dan berimbang selama satu siklus produksi.

Dengan beberapa permasalahan kualitas seperti tersebut di atas maka perlu penerapan pemupukan tanaman durian secara tepat dan berimbang. Menurut Santoso (2013), pemupukan tepat dalam arti tepat jenis, dosis, waktu, dan cara pelaksanaan. Berimbang dimaksudkan memberikan pupukdengan komposisi sesuai dengan kebutuhan. Tepat jenis dan tepat dosis, berhubungandengan komposisi pupuk yang diperlukan berkaitan dengan karakter tanaman.

\section{Promosi}

Promosi merupakan langkah penting yang dapat ditempuh oleh petani, pedagang, maupun pemerintah kabupaten dalam rangka meningkatkan minat konsumen terhadap durian lokal, khususnya durian Jember. Sentra produksi buah durian di Kabupaten Jember ini meliputi Kecamatan Panti, Sumberbaru, Sumberjambe, dan Jelbuk (Disperindag dan ESDM Kabupaten Jember, 2015). Konsumen durian lokal yang ada di Kabupaten Jember tidak hanya dari dalam wilayah kabupaten saja, melainkan juga berasal dari luar Kabupaten Jember seperti Banyuwangi, Lumajang, Bondowoso, Situbondo, dan Probolinggo.

Dalam upaya promosi buah durian lokal Jember, pemerintah daerah Kabupaten Jember yang dalam hal ini meliputi Bupati dan Camat setempat penghasil durian seperti Camat Sumberjambe dan Panti serta petani dan pedagang perlu untuk terus bekerjasama mengadakan promosi yang gencar agar dapat menarik konsumen durian. Campur tangan masyarakat Jember pun sangat diperlukan dalam pencapaian tujuan ini, misalnya dengan melakukan promosi secara on line melalui internet dan berbagai media sosial (misalnya Facebook, Instagram, Blog, Path, dsb) yang sekarang telah banyak dimiliki oleh tiap orang.

Beberapa kegiatan promosi yang pernah dilakukan dalam upaya meningkatkan pangsa pasar atau minat konsumen terhadap durian lokal khususnya durian Jember yakni dengan adanya lomba kejuaraan nasional untuk durian yang pernah diikuti oleh petani durian Jember pada tahun 2013 lalu (Antara News, 2012). Selain itu, petani durian yang berasal dari Jember juga sering kali mengikuti festival-festival lomba durian yang diadakan di beberapa daerha misalnya Banten dan Pekalongan.Acara promosi lain yang pernah diadakan di Jember yakni yang telah dilaksanakan pada tanggal 28 Februari hingga 7 Maret 2009 lalu di Ex. TPK 
Perhutani Jubung - Jember dilaksanakan Pesta Durian "Sepekan Durian Sumberjambe". Pengunjung bisa langsung mengkonsumsi durian kelas 1 di tempat acara, dimana durian-durian tersebut berasal dari durian Sumberjambe. Dari kegiatan Sepekan Durian Sumberjambe tersebut berhasil menjual durian sebanyak 7.338 buah dengan nilai transaksi Rp. 140 juta lebih (Disperindag dan ESDM Kabupaten Jember, 2015). Bentuk promosi lain yang akan dilakukan salah satunya oleh Camat Sumberjambe yakni pihak kecamatan akan membentuk Desa Wisata di Kecamatan Sumberjambe dengan tanaman durian sebagai icon utamnya.

Beberapa upaya yang telah dan akan ditempuh oleh berbagai pihak dalam upaya mempromosikan buah durian lokal Jember tentunya membutuhkan kerjasama, dukungan, dan keberlanjutan. Dengan adanya upaya-upaya tersebut diharapkan durian Jember akan lebih dikenal dan disukai oleh konsumen luas dari berbagai daerah.

\section{KESIMPULAN}

Berdasarkan hasil penelitian dan pembahasan, maka dapat diambil beberapa simpulan diantaranya:

1. Karakteristik konsumen durian lokal berdasarkan kategori: (a) umur mayoritas responden berada pada golongan umur 27-37 tahun, (b) jenis kelamin mayoritas konsumen adalah Perempuan dengan jumlah 47 orang, (c) mayoritas bekerja sebagai pegawai Swasta (d) tingkat pendidikan, mayoritas berada pada tingkat pendidikan SMP, (e) jumlah anggota keluarga, 2 hingga 4 orang (f) tingkat pendapatan, berada pada kategori sedang.

2. Dari 11 faktor yang mempengaruhi dalam preferensi konsumen memilih buah durian lokal terkategori menjadi 5 faktor yakni:

a) faktor warna kulit buah (hijau-muda, hijau-tua, hijau-cokelat, dan cokelattua); b) faktor panjang duri (pendek, sedang, dan panjang);

c) faktor warna daging cerah (kuning dan merah);

d) faktor tekstur (lembut-basah, lembutkering/pulen, berkrim, dan berserat); dan

e) faktor rasa buah durian (manis-pahit, manis-legit, manis-sedang, dan kurang manis).

3. Beberapa alternatif strategi yang dapat ditempuh dalam mengem-bangkan minat konsumen terhadap durian lokal diantaranya:

a. Penerapan teknologi bibit unggul

b. Omekanis maupun kimiawi

c. Peningkatan kualitas dari segi budidaya, segi panen, dan pasca panen harus diperhatikan dengan baik.

\section{DAFTAR PUSTAKA}

Santoso, Panca. 2010. Indonesia Berpotensi Produksi Durian Sepanjang Tahun. Artikel. Buletin Sinartani Badan Litbang Pertanian. Edisi 19-25 Desember 2012 No.3487 Tahun XLIII

Santoso, S. 2006. Menggunakan SPSS untuk Statistik Multivariat. Elex Media Komputindo, Jakarta.

Sianipar J.P.G. dan Entang. H.M 2003. Teknik-Teknik Analisis manajemen. Lembaga Administrasi Negara, Jakarta.

Simamora, B. 2004. Panduan Riset Perilaku Konsumen. PT Gramedia Pustakaa Utama. Jakarta.

Sugiono. 2006. Analisis tentang Faktorfaktor yang Mempengaruhi Perilaku Konsumen (Tinjauan Teori). Jurnal Aplikasi Manajemen. Volume 5 No. 2, Agustus 2006.

Sugiyono. 2006. Metode Penelitian Kuantitatif dan Kualitatif. Alfabeta. Bandung. 
Sayyidah dkk: Karakteristik dan Preferensi Konsumen Durian Lokal....

Suliyanto. 2005. Analisis Data dalam Aplikasi Pemasaran. Ghalia Indonesia, Bogor.Sumarwan, U. dan Agus Maulana. 2004. Perilaku Konsumen. PT Ghalia Indonesia. Bogor.
Sumarwan. 2004. Perilaku Konsumen, Teori dan Penerapannya dalam Pemasaran. Penerbit Kerja Sama : PT. Ghalia Indonesia dengan MMAInstitut Pertanian Bogor.

Sunarto. 2006. Perilaku Konsumen. AMUS. Yogyakarta. 